\title{
Ethno-pedagogy of Parents in Enforcement of Health Protocols to Change Students' Social Behavior
}

\author{
Sarmini1 ${ }^{1, *}$ Faridatul Lailiyah ${ }^{2}$ Sukma Perdana Prasetya ${ }^{2}$ Nuansa Bayu Segara ${ }^{2}$
}

\author{
${ }^{I}$ Department of Pancasila and Citizenship Education, Universitas Negeri Surabaya, Surabaya, Indonesia \\ ${ }^{2}$ Department of Social Studies Education, Universitas Negeri Surabaya, Indonesia \\ ${ }^{*}$ Corresponding author. Email: sarmini@unesa.ac.id
}

\begin{abstract}
Implementation of various laws and regulations regarding enforcement of the protocols of health to be an important dimension. Enforcement protocol health contains several values that are internalized into the binding value of social behavior. The substance of this research is how the parents of the status of civil servants construct protocols of health in building the social behavior of the child. The goal is to determine the urgency and the source of value Ethno-pedagogy parents do. The design used was a case study. Subjects were parents of students in SMPN 6 Surabaya, who work as civil servants. Data collection techniques used are questionnaires. The technique of data analysis uses the technique of percentage. The results of this study show, First Ethno-pedagogy enforcement protocol health is influenced by: (1) knowledge, in this case, the internalization of a variety of rules of government policies that should be implemented; (2) experience, is obtained from the exposed person; (3) the value of the religious, socio-cultural, especially related to the value of discipline, away from the crowd and reduce the mobility of the; and (4) environment, a space where enforcement was done at home and office. Second, the legislation on the enforcement of the protocol of the health and value norms, including religious values, as a source of value ethno-pedagogy. This study provides recommendations that the internalization of the value of the various laws and regulations enforcement protocol health needs space, media and educational strategies new habits through education in the family.
\end{abstract}

Keywords: Health Protocol, Parents, Social Behavior Ethno-pedagogy.

\section{INTRODUCTION}

Corona Virus Disease (Covid-19) has affected people around the world[1], can cause death, and is designated a global pandemic [2]. Even humans without Covid-19 symptoms can also spread this virus to other humans [3]. More than a year has passed, on March 24, 2021, it was recorded that additional cases still occur in the world, including in Indonesia, namely, there are 1,476,452 confirmed cases, 39,983 cases died, and 1,312,543 cases recovered [4]. In Indonesia, efforts to prevent Covid-19 are reflected in government Law Number 6 of 2018 which is a concern in Health Quarantine.

Indonesia as an affected COVID-19 country has designed and implemented various policies to reduce COVID-19. Applicable policies; (1) Republic of Indonesia Health Minister make a regulation No. 9 of 2020 which concern as the Guidelines for Large-Scale Social Restrictions was issued, by implementing 3M (Wearing a mask, cleaning hands soap with water, and keep a distance and 3T (Testing, Tracking, Treatment)
[5]; and (2) the implementation of the 5M health protocol includes wearing masks, cleaning hands by soap with water, keep distance from crowds, and limiting interaction and mobilization [6] in accordance with Presidential Instruction No. 2020 concerning Increasing Discipline of Health Protocol Law Enforcement to prevent and Control of Covid-19 during the Enforcement of Community Activity Restrictions (PPKM) on a Micro scale to PPKM by using the level of emergency distribution. The essence of this policy is that the community maintains health and does not make direct contact with people who are infected. confirmed Covid19.

Various impacts arise such as the occurrence of panic buying, a change in more limited work methods, an increase in stress levels, difficulties in social relations with family, an increase in the number of unemployed due to layoffs, increased divorce rates, lack of social interaction, the emergence of fear in various sociocultural aspects, health and others. 
The fear that arises as a result of the virus is a basic human psychological conflict. This proves that the presence of Covid-19 threatens most people to become a stressor, and the impact can be as severe as the impact if infected with Covid-19 [7]. Government makes various efforts to maintain the spread of Covid-19, one of which is by providing sanctions for people who violate the rules. The result was unexpected, thousands of health protocol violators were found during the implementation of PPKM since early 2021 in Sidoarjo. Generally, protocol violations that occur are not wearing masks, crowding, and doing mobility.

Therefore, a collaboration between local wisdom and community behavior is needed. Starting from the family scope and in the wider social environment, the implementation of health protocols can be done with ethno-pedagogy. Ethno-pedagogy views as a source of innovation and skills knowledge of local wisdom can be empowered for the welfare of the community. The characteristics and functions of local wisdom are 1) markers of community identity, 2) social cohesion glue, 3 ) cultural elements that grow from below, exist and develop 4) provide togetherness for certain communities, 5) change individual mindsets and relationships. and groups and 6) able to encourage the establishment of togetherness, appreciation, and joint mechanisms [8].

In line with this, the meaning and symbols of the community behavior framework are not located in people's heads but are shared with community members and are public [9]. This shows the configuration of learned behavior, its constituent elements are supported and passed on by certain members of the community. As with current conditions, the impact of the pandemic has a major influence on the pace of social change, because the social changes that occur include changes that are not wanted (intended change) by the community [10]. These social changes affect changes in people's behavior in the implementation of health protocols [11]. There are two behavioral changes, namely obeying and ignoring health protocols. The dominant factor of behavior in the category that ignores the government's appeal comes from the public's trivial perception of Covid-19 so that various violations are still found in the enforcement of health protocols in the community. On the other hand, people who know Covid-19 are directly proportional to compliance with health protocols.

This condition shows that the resolution of the pandemic is both the responsibility of the government and the active participation of the entire community, including schools and families (parents). In schools, ethno-pedagogy is used as a reflection of local content in learning that is useful for preparing students to face global challenges and love the homeland [12]. In the family environment, ethno-pedagogy is an activity related to guiding children and is sourced from cultural values that become standards of behavior [13] so that parents have an important role in enforcing health protocols. One of them is to socialize with children regarding things that can and cannot be done during a pandemic.

In addition to the beliefs, values, and norms that are guided, some media are used by parents such as television and social media (WhatsApp, Instagram, YouTube). This is done by parents to set an example in preventive measures, provide assistance, provide explanations, and persuade especially for children who have difficulty implementing health protocols [14]. The role of parents that should be carried out by mothers and fathers is more carried out by mothers than fathers. The cooperation of both parents is important to socialize matters related to Covid-19 including health protocols to children [15]. In addition to bringing up limitations in the midst of a pandemic, there are opportunities for families to cultivate the quality of interaction between their members.

The success of parents in playing themselves in enforcing health protocols in children can be determined from knowledge. The driving factor can be influenced by the source of information that supports knowledge. For working parents, this knowledge comes from the value framework of community behavior and various internalized regulations, for example, parents who are civil servants. This employee must implement and comply with all policies made by the government, as well as must be in line with the role of the values he believes in. This is where the dilemma of behavior in implementing health protocols arises, between at home and at the office. It is interesting to study how parents who are civil servants understand and construct health protocols in building students' social behavior at home. This study's purpose is to determine the importance of the source of ethno-pedagogical values by parents who work as civil servants.

\section{METHOD}

This research used a qualitative method with a case study approach. This research focuses intensively on one particular object that is studied as a case, namely the Importance of Ethno-pedagogy for Enforcement of Health Protocols in the Perspective of Community Culture. This study's subjects were parents of students with the status of civil servants at SMPN 6 Sidoarjo. The number of parents who have a livelihood as Civil Servants, know information about health protocols, and who fill out questionnaires is 50 people.

The focus in this study is ethno-pedagogy or internalization of the values of parents with the status of Civil Servants in constructing the enforcement of health protocols to change students' social behavior. The substance of this research is divided into four indicators, namely: (1) the importance of enforcing health protocols; (2) Legal Basis for enforcing health protocols; (3). Community Culture: Enforcement of Health Protocols, 
and (4) Implementation and challenges of Enforcement of Health Protocols. The data analysis technique used descriptive statistics obtained from questionnaire data collection, calculated by the percentage technique.

\section{RESULTS AND DISCUSSION}

\subsection{Parental Health Protocol Overview}

Health protocol is a guideline way that must be done to prevent and maintain the Covid-19 spreading. This context has been done to protect oneself from the possibility of being exposed to the virus even though several types of vaccines have been found but have not been specifically appropriate to fight viruses from various existing variants [16]. Such conditions indicate that the public needs to know and apply health protocols during the pandemic. Questionnaires were given online to 50 parents of SMPN 6 Sidoarjo students who work as Civil Servants. Based on the results of the questionnaire there were 50 respondents in this study. Informant profiles are contained in Table 1

Table 1 shows the profile of the subjects in this study. It is known that the age of the respondents is between 2252 years which is divided into the age of 22-32 years (48\%), 33-42 years (32\%), and the age of 43-52 years (20\%). Most of the respondents who filled out were women, it was proven that there were $70 \%$ women and $30 \%$ men. The profession of civil servant parents is spread from various types of work; sub-district employees (6\%), elementary school teachers $(30 \%)$, junior high school teachers (20\%), high school teachers (10\%), nurses (10), midwives (14\%), and hospital IT personnel (10\%).

Table 1. Profile of Research Subjects.

\begin{tabular}{|l|c|}
\hline \multicolumn{1}{|c|}{ Table of Respondents Profile } & Total (\%) \\
\hline Age (years) & 48 \\
\hline 22-32 years & 32 \\
\hline $33-42$ years & 20 \\
\hline 43-52 years \\
\hline Gender & 70 \\
\hline Female & 30 \\
\hline Male \\
\hline Profession Parents (PNS) & 6 \\
\hline Sub-district employees & 30 Middle \\
\hline Elementary school teachers & 20 \\
\hline school & 10 \\
\hline teachers high school teachers & 10 \\
\hline Nurses & 14 \\
\hline Midwives & 10 \\
\hline Hospital IT personnel &
\end{tabular}

Source: Research Questionnaire
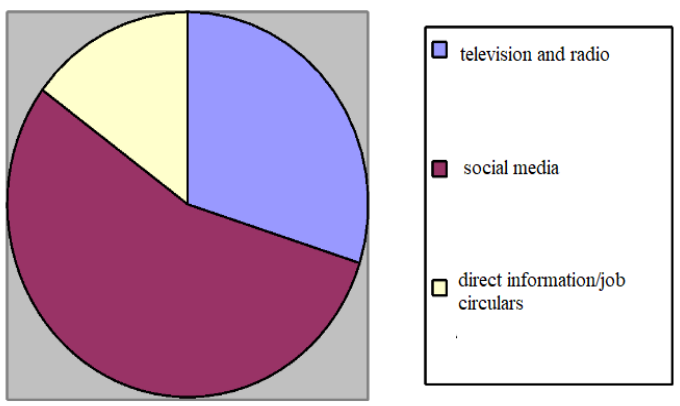

Figure 1. Respondent's Diagram
From the fifty parents, most of them knew information related to health protocols. However, differences emerged from the first time they received information on the health protocol. There are $30 \%$ of respondents who said that they first learned about health protocol information from television and radio, 55\% from social media, and $15 \%$ from circulars given directly to respondents because of their work as health workers (See Picture Diagram 1). This shows that most parents of SMPN 6 Sidoarjo students get information about health protocols from social media.

\subsection{Enforcement of Health Protocols in the Ethno-pedagogical Perspective of Parents}

There are 4 indicators of health protocol enforcement in the Ethno-pedagogy perspective of parents, including (1) the importance of enforcing health protocols; (2) Legal Basis for enforcing health protocols; (3). Community Culture: Enforcement of Health Protocols, and (4) Implementation and challenges of Enforcement of Health Protocols. The data is broken down in table 2 .

Table 2. Ethno-Pedagogy Recapitulation Parents In The Enforcement Of Health Protocols To Change Students' Social Behavior

\begin{tabular}{|c|c|c|c|c|c|c|}
\hline \multirow[t]{2}{*}{ No } & \multirow[t]{2}{*}{ Aspects assessed } & \multicolumn{5}{|c|}{ Scale/Percentage } \\
\hline & & 1 & 2 & 3 & 4 & 5 \\
\hline \multicolumn{2}{|r|}{$\begin{array}{l}\text { A. The Importance of Enforcing } \\
\text { Health Protocols Health }\end{array}$} & & & & & \\
\hline 1 & $\begin{array}{l}\text { protocols are efforts made by } \\
\text { every citizen as a form of self- } \\
\text { prevention and reducing the } \\
\text { spread of disease that is } \\
\text { endemic and for the common } \\
\text { good }\end{array}$ & & & & $\begin{array}{c}5 \\
(10 \%)\end{array}$ & $\begin{array}{c}45 \\
(90 \%)\end{array}$ \\
\hline 2 & $\begin{array}{l}\text { There are } 5 \text { health protocol } \\
\text { behaviors to prevent and } \\
\text { maintain covid- } 19 \text { spreading } \\
\text { that must be carried out in the } \\
\text { family and office environment, }\end{array}$ & & & & & $\begin{array}{c}50 \\
(100 \%\end{array}$ \\
\hline 3 & $\begin{array}{l}\text { Sources of religious values and } \\
\text { other values in society }\end{array}$ & & & & $\begin{array}{c}45 \\
(90 \%)\end{array}$ & $\begin{array}{c}5 \\
(10 \%)\end{array}$ \\
\hline 4 & $\begin{array}{l}\text { Government regulations } \\
\text { through the policy of limiting } \\
\text { activities starting from PSBB to } \\
\text { Emergency PPKM Level } 4 \\
\text { make you have to implement } \\
\text { health protocols, both in the } \\
\text { family and office environment }\end{array}$ & $\begin{array}{c}5 \\
(10 \%)\end{array}$ & & & $\begin{array}{c}5 \\
(10 \%)\end{array}$ & $\begin{array}{c}40 \\
(80 \%)\end{array}$ \\
\hline 5 & $\begin{array}{l}\text { work requires you to implement } \\
\text { health protocols strictly }\end{array}$ & $\begin{array}{c}10 \\
(20 \%)\end{array}$ & & & $\begin{array}{c}10 \\
(20 \%) \\
\end{array}$ & $\begin{array}{c}30 \\
(60 \%)\end{array}$ \\
\hline 6 & $\begin{array}{l}\text { Experiences of relatives, } \\
\text { neighbors, family, and closest } \\
\text { people who have been } \\
\text { confirmed positive }\end{array}$ & & & & $\begin{array}{c}5 \\
(10 \%)\end{array}$ & $\begin{array}{c}45 \\
(90 \%)\end{array}$ \\
\hline 7 & $\begin{array}{l}\text { Father/mother getting more of } \\
\text { and access to information } \\
\text { related to health protocol of } \\
\text { media messaging }\end{array}$ & & & & $\begin{array}{c}5 \\
(10 \%)\end{array}$ & $\begin{array}{c}45 \\
(90 \%)\end{array}$ \\
\hline 8 & $\begin{array}{l}\text { Mr. /mothers ask their children } \\
\text { to get and access information } \\
\text { related to health protocols from } \\
\text { social media such as } \\
\text { WhatsApps and Telegram, } \\
\text { Facebook, Instagram, } \\
\text { YouTube, Twitter }\end{array}$ & $\begin{array}{c}20 \\
(40 \%)\end{array}$ & & & $\begin{array}{c}10 \\
(20 \%)\end{array}$ & $\begin{array}{c}20 \\
(40 \%)\end{array}$ \\
\hline 9 & $\begin{array}{l}\text { fathers/mothers access } \\
\text { information related to health } \\
\text { protocols from electronic media } \\
\text { such as television and radio }\end{array}$ & & & & $\begin{array}{c}5 \\
(10 \%)\end{array}$ & $\begin{array}{c}45 \\
(90 \%)\end{array}$ \\
\hline $\begin{array}{l}1 \\
0\end{array}$ & $\begin{array}{l}\text { Cultural values adopted by the } \\
\text { surrounding environment affect } \\
\text { compliance with health } \\
\text { protocols }\end{array}$ & $\begin{array}{c}10 \\
(20 \%)\end{array}$ & & & $\begin{array}{c}5 \\
(10 \%)\end{array}$ & $\begin{array}{c}35(70 \\
\%)\end{array}$ \\
\hline & $\begin{array}{l}\text { egal Basis for Enforcing } \\
\text { Ith Protocols }\end{array}$ & & & & & \\
\hline
\end{tabular}




\begin{tabular}{|c|c|c|c|c|c|c|}
\hline 11 & $\begin{array}{l}\text { issuance of Regulation of the } \\
\text { Minister of Health of the } \\
\text { Republic of Indonesia Number } \\
9 \text { of } 2020 \text { concerning the } \\
\text { implementation of the } 5 \mathrm{M} \\
\text { health protocol }\end{array}$ & & $\begin{array}{c}15 \\
(30 \%)\end{array}$ & $\begin{array}{c}10 \\
(20 \%)\end{array}$ & $\begin{array}{c}10 \\
(20 \%)\end{array}$ & $\begin{array}{c}15 \\
(30 \%)\end{array}$ \\
\hline 12 & $\begin{array}{l}\text { Health protocols have made } \\
\text { you aware to care more about } \\
\text { health, including changing a } \\
\text { clean and healthy lifestyle }\end{array}$ & $\begin{array}{c}15 \\
(30 \%)\end{array}$ & & & $\begin{array}{c}10 \\
(20 \%)\end{array}$ & $\begin{array}{c}25 \\
(50 \%)\end{array}$ \\
\hline 13 & $\begin{array}{l}\text { The substance of health } \\
\text { protocol enforcement has been } \\
\text { taught following the religious } \\
\text { values that you believe in }\end{array}$ & & & & $\begin{array}{c}10 \\
(20 \%)\end{array}$ & $\begin{array}{c}40 \\
(80 \%)\end{array}$ \\
\hline 14 & $\begin{array}{l}\text { Cultural values that are used as } \\
\text { a blueprint for community } \\
\text { behavior can be used as The } \\
\text { basic principles in enforcing } \\
\text { health protocols are recognized } \\
\text { and carried out together in } \\
\text { social life }\end{array}$ & $\begin{array}{c}20 \\
(40 \%)\end{array}$ & & & $\begin{array}{c}10 \\
(20 \%)\end{array}$ & $\begin{array}{c}20 \\
(40 \%)\end{array}$ \\
\hline \multicolumn{2}{|c|}{$\begin{array}{l}\text { C. Community Culture: } \\
\text { Enforcement of Health Protocols }\end{array}$} & & & & & \\
\hline 15 & $\begin{array}{l}\text { Cleaning hands with soap and } \\
\text { flowing water is one of the } \\
\text { health protocol behaviors that } \\
\text { existed before the pandemic }\end{array}$ & & & & $\begin{array}{c}10 \\
(20 \%)\end{array}$ & $\begin{array}{c}40(80 \\
\%)\end{array}$ \\
\hline 16 & $\begin{array}{l}\text { The role of community leaders } \\
\text { and religious leaders in } \\
\text { disseminating health protocols }\end{array}$ & $\begin{array}{c}15 \\
(30 \%)\end{array}$ & & & $\begin{array}{c}10 \\
(20 \%)\end{array}$ & $\begin{array}{c}25 \\
(50 \%)\end{array}$ \\
\hline 17 & $\begin{array}{l}\text { Keeping a distance becomes a } \\
\text { difficult thing to do as a whole } \\
\text { because the culture that is } \\
\text { inherent in the community is } \\
\text { harmonious }\end{array}$ & & & & $\begin{array}{c}5 \\
(10 \%)\end{array}$ & $\begin{array}{c}45 \\
(90 \%)\end{array}$ \\
\hline 18 & $\begin{array}{l}\text { Enforcement of health } \\
\text { protocols away from crowds is } \\
\text { strongly influenced by the habit } \\
\text { of carrying out group activities } \\
\text { such as religious rituals }\end{array}$ & & & & $3(6 \%)$ & $\begin{array}{c}47(94 \\
\%)\end{array}$ \\
\hline 19 & $\begin{array}{l}\text { Understanding of information } \\
\text { related to the enforcement of } \\
\text { health protocols in the } \\
\text { community is influenced by the } \\
\text { culture adopted and belief in } \\
\text { social life }\end{array}$ & & & & $\begin{array}{c}5 \\
(10 \%)\end{array}$ & $\begin{array}{c}45 \\
(90 \%)\end{array}$ \\
\hline 20 & $\begin{array}{l}\text { Human nature as a social being } \\
\text { determines a person, both } \\
\text { individually and in groups, to } \\
\text { have a high level of } \\
\text { mobilization and interaction. }\end{array}$ & & & & $2(4 \%)$ & $\begin{array}{c}48 \\
(96 \%)\end{array}$ \\
\hline \multicolumn{2}{|c|}{$\begin{array}{l}\text { D. Implementation and Challenges } \\
\text { of Enforcement of Health } \\
\text { Protocols }\end{array}$} & & & & & \\
\hline 21 & $\begin{array}{l}\text { The religious values approach } \\
\text { can be used to implement the } \\
\text { enforcement of health protocols } \\
\text { such as wearing masks, } \\
\text { cleaning hands, keeping the } \\
\text { distance, and staying away } \\
\text { from crowds }\end{array}$ & $\begin{array}{c}25 \\
(50 \%)\end{array}$ & & $\begin{array}{c}15 \\
(30 \%)\end{array}$ & & $\begin{array}{c}10 \\
(20 \%)\end{array}$ \\
\hline 22 & $\begin{array}{l}\text { Work From Home (WFH) is a } \\
\text { form of implementing the health } \\
\text { protocol that reduces the } \\
\text { mobilization and interaction }\end{array}$ & & & & & $\begin{array}{c}50 \\
(100 \%)\end{array}$ \\
\hline 23 & $\begin{array}{l}\text { Civil Servants (PNS) should be } \\
\text { a pioneer in rectifying the } \\
\text { circulation of information Hoax }\end{array}$ & $\begin{array}{c}15 \\
(30 \%)\end{array}$ & & $\begin{array}{c}5 \\
(10 \%)\end{array}$ & $\begin{array}{c}15 \\
(30 \%)\end{array}$ & $\begin{array}{c}15 \\
(30 \%)\end{array}$ \\
\hline 24 & $\begin{array}{l}\text { enforcement of health protocols } \\
\text { when at home influenced by } \\
\text { government policies and efforts } \\
\text { to maintain the Covid-19 } \\
\text { spreading rather than the } \\
\text { culture that already exists and } \\
\text { is inherent in the community }\end{array}$ & $\begin{array}{c}30 \\
(60 \%)\end{array}$ & $\begin{array}{c}10 \\
(20 \%)\end{array}$ & & $\begin{array}{c}10 \\
(20 \%)\end{array}$ & \\
\hline 25 & $\begin{array}{l}\text { Health enforcement when in the } \\
\text { workplace is more determined } \\
\text { from superior rules sourced } \\
\text { from government law }\end{array}$ & & & & & $\begin{array}{c}50 \\
(100 \%)\end{array}$ \\
\hline 26 & $\begin{array}{l}\text { There is a difference in } \\
\text { treatment in efforts to enforce } \\
\text { health protocols between at } \\
\text { home and at work }\end{array}$ & $\begin{array}{c}5 \\
(10 \%)\end{array}$ & & $\begin{array}{c}5 \\
(10 \%)\end{array}$ & $\begin{array}{c}10 \\
(20 \%)\end{array}$ & $\begin{array}{c}30 \\
(60 \%)\end{array}$ \\
\hline 27 & $\begin{array}{l}\text { Culture is the dominant factor } \\
\text { in reducing mobilization and }\end{array}$ & $\begin{array}{c}20 \\
(40 \%)\end{array}$ & & \begin{tabular}{c|c}
5 \\
$(10 \%)$
\end{tabular} & $\begin{array}{c}5 \\
(10 \%) \\
\end{array}$ & $\begin{array}{c}20 \\
(40 \%) \\
\end{array}$ \\
\hline
\end{tabular}

\begin{tabular}{|c|c|c|c|c|c|}
\hline & $\begin{array}{l}\text { interaction during health } \\
\text { protocol enforcement }\end{array}$ & & & & \\
\hline 28 & $\begin{array}{l}\text { Active community participation } \\
\text { determines and influences a } \\
\text { person's level of adherence to } \\
\text { health protocols }\end{array}$ & & & & $\begin{array}{c}50 \\
(100 \\
\%)\end{array}$ \\
\hline 29 & $\begin{array}{l}\text { Active and effective } \\
\text { communication is the main } \\
\text { factor in efforts to enforce } \\
\text { health protocols both in the } \\
\text { home environment, work } \\
\text { environment, and social } \\
\text { environment }\end{array}$ & $\begin{array}{c}5 \\
(10 \%)\end{array}$ & $\begin{array}{c}5 \\
(10 \%)\end{array}$ & $\begin{array}{c}10 \\
(20 \%)\end{array}$ & $\begin{array}{c}30 \\
(60 \%)\end{array}$ \\
\hline 30 & $\begin{array}{l}\text { Establish cooperation from all } \\
\text { sectors m starting from RT, } \\
\text { RW, Village/Kelurahan, } \\
\text { religious leaders, community } \\
\text { leaders, to the central } \\
\text { government }\end{array}$ & & & $\begin{array}{c}5 \\
(10 \%)\end{array}$ & $\begin{array}{c}45 \\
(90 \%)\end{array}$ \\
\hline
\end{tabular}

Information:

1. Strongly Disagree

2. Disagree

3. Agree

4. Strongly Agree

5. Strongly Agree

Based on the indicators of enforcement of health protocols in the ethno-pedagogical perspective of parents, it can be seen that:

\subsubsection{The Importance of Enforcing Health Protocols}

Subjects of this study assessed that $80 \%$ of students' parents agreed that government regulations through policies ranging from PSBB to PPKM Level 4 made them aware of implementing health protocols in the family and office environment. This is directly proportional to the reason that $90 \%$ of respondents implement health protocols as a form of self-prevention and reduce the spread of disease and for the common good. Personal and work experiences were also assessed as triggers for them to implement the health protocol, with $90 \%$ of respondents strongly agreeing with the statement. In addition to government policies, the source of religious and cultural values adopted by the surrounding environment also affects compliance with health protocols. This condition illustrates that the implementation of health protocols during this pandemic is not only the focus of the government but also personal awareness, religious values, and culture adopted by the community in their social environment.

\subsubsection{Legal Basis for Enforcing Health Protocols}

Behind the awareness of respondents regarding the importance of implementing health protocols, there are pros and cons in the community, namely $30 \%$ of students' parents who strongly agree and disagree regarding guidelines for enforcing health protocols sourced from government policies. $80 \%$ of respondents said that public compliance does not always come from government regulations, but people believe that the substance of the enforcement of this health protocol has been taught in accordance with the religious values they believe in. The majority of the Muslim community recognizes that to deal with Covid-19, it is necessary to have good immunity. In Islam, it is recommended to strive both medically and theologically. Medical efforts include adequate rest, not sleeping too late at night, eating a 
balanced diet, drinking at least 1.5 liters of water per day, exercising, and if necessary taking multivitamins. Theological commitments include increasing multiply prayers, increasing alms, patiently undergoing all scenarios of Allah, always remembering Allah, and praying non-stop to relieve stress and make you happy.

This condition refers to the argument that cultural values that are used as a blueprint for community behavior can be used as a basis for upholding health protocols that are recognized and carried out together in social life. Through this, they can make them aware to be more concerned about health, including changing a clean and healthy lifestyle. So it can be seen that the legal basis for enforcing health protocols on parents of SMPN 6 Sidoarjo students is more based on religious law as part of religious culture in addition to government regulations.

\subsubsection{Community Culture: Enforcement of Health Protocols Community}

Culture is evident when $50 \%$ of respondents agree that the role of community leaders and religious leaders has an important role in disseminating health protocols, including influencing them in developing children's social behavior. So that it supports the majority of respondents $(90 \%)$ belief that the understanding of information on enforcement of health protocols in the community is strongly influenced by the culture adopted and belief in social life. This can be proven from components of health protocols such as hand washing that existed before the pandemic, for example washing hands before entering holy areas (tombs, places of worship), and the habit of washing hands before/after eating, and before going to bed.

The dilemma occurs when the components of a health protocol are inversely related to the culture of the community, for example keeping the distance, staying away from crowds area, and decreasing mobilization and interaction. The nature of humans as social beings has made it difficult for people to quickly adapt to new habits because the inherent culture in the community is mutual harmony, establishing physical closeness as a form of mutual respect, respect, as well as the habit of shaking hands, accustomed to carrying out group activities such as religious ritual activities. Various local and national cultural celebrations, and the tendency to have a desire to mobilize and interact with their social environment. Therefore, a cultural approach is needed in enforcing health protocols in the community.

\subsubsection{Implementation and Challenges of Enforcement of Health Protocols}

There were differences in the way the health protocols were implemented by the subjects in this study. This can be proven when parents are at work, $100 \%$ of them agree that health enforcement in the workplace is determined more by superior rules that come from government policies. This is realized directly through the implementation of Work From Home for civil servants, as a form of implementation of restrictions on mobilization, interaction, maintaining distance, and staying away from crowds. $60 \%$ of research subjects admitted that there were differences in enforcement treatment at home and the office. If they are at home they are more influenced by the culture that already exists and is inherent in the community, rather than government policies. However, some of them also admit that the approach of religious values is not always used to implement the enforcement of health protocols $(50 \%)$. Half of them $(50 \%)$ believe that the effort that must be made in enforcing health protocols comes from active community participation, active and effective communication in the family, office, and social space, as well as establishing cooperation from all sectors from RT/RW to government. center to jointly enforce health protocols to increase success in changing social behavior, including preventing the spread of Covid-19.

\subsection{Ethno-pedagogy of Parents in Enforcement of Health Protocols to Change Students' Social Behavior}

The ethno-pedagogy of enforcing parental health protocols to build students' social behavior while at home is reflected in the process of socialization and parenting to children. Indirectly, parents instill that life cannot be separated from the culture that exists in society, so adapting is an important point to be implemented without exception in efforts to enforce health protocols in the family environment. Like washing hands, most parents admit that this habit is not foreign, incorporating religious and socio-cultural values could make students easier to understand the intent of policies in health protocols. Although in practice parents also recognize the difference in treatment between at home and the office, they try to balance government policies with local culture.

Through an ethno-pedagogical approach that is carried out not only at school but also carried out at home, it can provide opportunities for students to demonstrate the achievement of the understanding they have created and manifest in behavioral changes to prepare themselves for new habits. This condition refers to the argument that cultural values that are used as a blueprint for community behavior can be used as a basis for enforcing health protocols that are recognized and implemented together in social life. Through this, they can make them aware to be more concerned about health, including changing a clean and healthy lifestyle

\section{CONCLUSION}

Several things can be concluded. First, the ethnopedagogy of parents in enforcing health protocols to build students' social behavior at home is strongly influenced by community construction, which is influenced by: (1) knowledge, in this case, the internalization of various government policy rules that must be implemented; (2) experience, gained from people who have been exposed; (3) religious, sociocultural values, especially related to the value of discipline, enforcement to stay away from crowds and 
reduce mobility; and (4) the environment, the space where the enforcement is carried out, namely the family room and office. Second, there are two sources of ethnopedagogical value in the enforcement of health protocols, namely (1) various laws and regulations regarding health protocols, which are internalized as part of community values, and; (2) norm values that guide community behavior. Third, the internalization of the values of various laws and regulations for enforcing health protocols requires appropriate space, media, and educational strategies to become shared values that are owned and bound by the community. This condition shows that the existence of ethno-pedagogy is important in the enforcement of health protocols, especially to make it easier for students to adapt to new habits in their social life.

\section{ACKNOWLEDGMENTS}

Acknowledgments submitted to the Rector of State University of Surabaya, which has provided funding of research, with the Rector Decree No. 837/UN/HK/PM/2021 Dated June 22, 2021, regarding the Determination of Policy Research Recipients of the Faculty of Social Sciences and Law, State University of Surabaya, PNBP Funds for 2021.

\section{REFERENCES}

[1] Cucinotta, D., \& Vanelli, M. (2020). WHO declares COVID-19 apandemic. Acta Bio-Medica : Atene Parmensis, 91(1), 157-160. https://doi.org/10.23750/abm.v91i1 .9397

[2] Lloyd-Sherlock, PG, Kalache, A., McKee, M., Derbyshire, J., Geffen, L., Casas, FG-O., \& Gutierrez, L.M. (2020). WHO must prioritize the needs of older people in its response to the covid-19 pandemic. BMJ (Clinical Research Ed.), 368(m1164), 1. https://doi.org/10.1136/bmj .m1164

[3] Kumar, M., \& Dwivedi, S. (2020). Impact of Coronavirus Imposed Lockdown on Indian Population and their Habits. 5(June), 88-97.

[4] Task Force for the Acceleration and Handling of Covid-19 (2021). Data on Covid-19 in Indonesia. Accessed at: http://bnpb.go.id

[5] Yunus, R. Nur. (2020). Lockdown Policy to Anticipate the Spread of the Corona Virus Covid-19. Journal of Social \& Cultural Syar-i. Vol. 7 No. 3 (2020), pp. 227-238.

[6] Song, F, Shi N, Shan F, Zhang Z, Shen J, Lu H et al. (2020). Emerging Corona virus 2019-nCoV Pneumonia. Radiology. https://dx.doi.org/10 .1148/radiol.2020200274

[7] Taylor, S. (2019). The Psychology of Pandemics: Preparing for the Next Global Outbreak of Infectious Disease. England: Cambridge Scholar Publishing.

[8] Utari, Unga. et al. (2016). Local Wisdom-Based Thematic Learning in Elementary Schools in Facing ASEAN Economic Community (AEC). Journal of
Social Studies Learning Theory and Practice. 1 (1):39-44.

[9] Geertz, Clifford. (1992). Cultural Interpretation Yogyakarta : Kanisius

[10] Soekanto, Soerjono. (2013). Sociology An Introduction. Jakarta : Rajawali Press

[11] Niruri, Rasmaya, Yeni Farida, Fea Prihapsara, Adi Yugatama, \& Siti Ma'rufah. (2021).Behavior Communityin Implementing Health Protocols as an Effort to Prevent Covid-19 at Pungawan, Banjarsari Surakarta. Pharmacon : Indonesian Pharmacy Journal. Vol. 18, No. 1, 75-81

[12] Sartini. (2010). Exploring the Local Wisdom of the Archipelago: A Study of Philosophy. Journal of Philosophy, 14(2): 111-120.

[13] Albaiti. (2015). Study of Local Wisdom of the Dani Cultural Group of the Baliem Valley, Wamena Papua. Journal Indonesian Archipelago Education. Vol. 1 No. 1

[14] Hajeni, Hadi Pajarianto, Personal Imam, Rahmatia, Nursaqinah Galugu, \& Sri Rahayu Amri. (2021). The Roleof Parents on Early Childhood Understanding of Covid-19 Based on the Religiosity Approach.Journal Obsession: Journal of Early Childhood Education. Volume 5 Issue 2, 2231-2240. DOI: 10.31004/obsesi.v5i2.1173

[15] Rohita, R. (2020). Introduction of Covid-19 in Preschool Age Children: Analysis on the Implementation of the Role of Parents at Home. Obsession Journal: Journal of Early Childhood Education, 5(1), 315. https://doi.org/10.31004 /obsesi.v5i1.528

[16] Gennaro, F. Di, Pizzol, D., Marotta, C., Antunes, M., Racalbuto, V., Veronese, N., \& Smith, L. (2020). Coronavirus Diseases (COVID-19) Current Status and Future Perspectives : A Narrative Review. International Journal of Environmental Research and Public Health, 17, 2-11. 